\title{
What is Behind the Bodice (Choli Ki Pichhe)? Narratives of Simulacra, Rape, Forced Whoredom: A Critical Analysis of Mahasweta Devi's Behind the Bodice
}

\author{
Sushil Sarkar 8 (D) \\ Assistant Professor, Department of English, Kashipur. Mahavidyalaya, Purulia, West Bengal, India \\ \ Corresponding Author: Sushil Sarkar, E-mail: sushilsarkar15@gmail.com
}

\author{
ARTICLE INFORMATION \\ Received: August 08, 2021 \\ Accepted: September 04, 2021 \\ Volume: 1 \\ Issue: 1 \\ DOI: $10.32996 /$ jgcs.2021.1.1.2
}

\section{KEYWORDS}

Simulacra, Hyper-Reality, Bodice, Gangrape, Prostitution, Unethical Media, Repressive State

Apparatus, Breast

\section{ABSTRACT}

Media is not a charitable organization rather a profitable institution. Media often fails to publish important national issues and success to publish the non-issues for escalating the mercantile gains. Interestingly, media often adopts simulation, simulacra, hyper-reality to printed or digitalized news applying their unethical derealization or yellow journalism. I, therefore, theoretically and thematically will show in my paper how this paid journalism and unethical media using a false representation of Gangor's breast doomed her life. This 'Simulacrum' gives birth of narratives of violence, gang rape, and forced prostitution in Mahasweta Devi's story Behind the Bodice. Jean Baudrillard defines 'Simulacra' as something that replaces reality with its false representation. According to him, it refers the false reality of the image and misrepresentation of true reality actually. In the story Behind the Bodice, Gangor's breast feeding of her child is a natural phenomenon. But this true reality, 'save the breast' (simulacra) is represented with erotic code which sells abroad by Upin Puri at huge prices. This ace-photographer exhibited the nakedness of India to the West for his journalistic prosperity. His false representations of Gangor's breasts germinate the tales of violence, eviction, male gaze, narratives of forced prostitution and finally, a tragic doom. I will highlight in my paper how this subject is appreciated by then. On the other hand, 'Behind the Bodice' introduces the narrative of simulacra, rape and forced whoredom by the power, politics and apparatus of the repressive state.

\section{Introduction}

A Hindi song became very popular a few years back. This song has become extravagantly popular, especially the young generation enthralled by the Hindi movie Khalnayak. 'Choli Ki Picche Kiya Hai, Choli Ki Picche', means "What is Behind the Bodice? Behind the Bodice?" Apparently, the song seems very erotic and obscene, but the latter part sounds very interesting. The next part of the song also sounds like 'Choli Me Dil Hain Mera, Yeh Dil Main Dongi Mere Yaar Ko, Yaar Ko'. In English translation, it is precisely like 'Behind the Bodice is my heart, this heart I will give to my lover, lover' (Self Translation). Mahasweta Devi deeply listened to the song and tried her hand to write about whatever was trickling in her brain relating to the women's breasts. That story is included in the translated works of Breast Stories, by the greatest postcolonial critic Gayatri Chakraborty Spivak. Mahasweta Devi herself answers the question of the song. She very thought-provokingly emphasizes the answer, which goes like that 'Behind the Bodice is the Middle East' (Behind the Bodice-01). What is the exact underlying meaning of the Middle East, intention of using the Middle East and the adaptation of the special region of the globe need a deep understanding of studies? But the word the Middle East as used in the story perhaps delivers us a specific 'Oriental Discourse'. According to Mahasweta Devi, "In order to bring the nation's brain home- and thus India suddenly discovered behind the bodice was the Middle East. This discovery is yet is another explanation. Because the edifice crumbled was it suddenly it is the Middle East that controls the putting on and taking off bodies and subsequent hanky-panky etc. (Behind the Bodice -01)". Thus the words 'Behind the Bodice' or 'Choli Ki Picche' becomes much more important than other national issues because "Thus everyone got busy to find out what was there: national media, censor board, anti-bra girls many associations, organizations on that state level etc - cable TV

\section{K C AL-KINDI CENTER R D FOR RESEARCH AND} Your gateway to world-class research

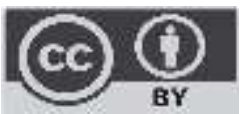

Published by Al-Kindi Center for Research and Development, London, United Kingdom. Copyright (c) the author(s). This open access article is distributed under a Creative Commons Attribution (CC-BY) 4.0 license 
channels -green eye shaded lady votarians, associations- all the religious groups and politicians. Watching Cassettes of 'Khalnayak' under cover became the 'Norm of the day (Behind the Bodice -02)". Based on that story of Mahasweta Devi, the Italian production by Italo Spinelli directed a film based on the story "Choli Ki Picche. After carefully studying the story, it is obvious that the word 'Bodice' becomes metaphorically a troupe of disaster that metamorphoses the heroine from innocence to experience and brings her final dooms. The story's theme is the real picture of the contemporary tribal India that Mahasweta Devi in this story is very amiably depicted after her first-hand experience and investigation. She also emphasizes in this story the real violence and marginalization condition among the second class citizens of India.

\section{Image of Gangor's Bodice as Simulacra}

Jean Baudrillard is a postmodern theorist, philosopher, and cultural theorist best known for analysing culture, media, and technological communication. In his well-researched book 'Simulacra and Simulation', translated by Sheila Faria Glaser says, "We have in a world where there is more and more information and less and less meaning (Simulacra and Simulation-55)". Baudrillard about postmodern culture says that our society and life has been so reliant on models and maps and advertisement that we have lost all contact with the real world that preceded that map. Reality itself has begun merely to imitate the model which now precedes and determines the real world: "The territory no longer precedes the map, nor does it survive it. Nevertheless, the map precedes the territory - precession of Simulacra- that engenders the territory (The Precession of Simulacra-01)". Mahasweta Devi's short story 'Behind the Bodice', Simulacra is a word that leads the story to the ultimate downfall of the female protagonist Gangor and creates a narrative of rape, violence and forced whoredom. How far this simulacrum applies to generating the violence, torture, rape and prostitution? To get the answer, we must peep into the original theme of the story 'Choli Ki Picchhe' or Behind the Bodice. The story 'Behind the Bodice' very realistically unfolds the tragedy of Gangor. Upin Puri, an ace photographer cum journalist, representative of metropolitan city and western media. He travels to Purulia for the photography of the 'semi famine condition' of that region. In that 'Semi famine Condition' of that locality creates an intense interest of Upin when he finds Gangor in her breastfeeding condition. "Works on piece wage basis in the kilns for the light bricks and tiles (Behind the Bodice 14). Upin takes a photograph of the breastfeeding young mother Gangor. Gangor did not object to the taking of the photo but instead "Put out her hand for money. Snap a photo so give me cash! (Behind the Bodice-14). The photography of Gangor's breast "The half-naked ample breasted female figures of Orissa are about to be raped. Save them! Save the Breast! (Behind the Bodice-139)". His photography heralds the misfortunes into the life of Gangor which she experienced in her later period of life. Upin sells the picture abroad at an exorbitant price in the leading newspaper and the message "Save them! Save the Breast!" becomes backfire and cause of violence upon Gangor's life. So this difference can be found in more clearly in the words of Mahasweta Devi obviously: "The tribals and the mainstream have always been parallel. There has never been a meeting point. The mainstream simply doesn't understand the parallel. As long as the forest was there, the hunting tribes didn't suffer so much because the forest provided them with food, shelter, timber, hunting, etc. But now that the forest was gone, the tribals were in dire distress. Some, like the Santals or the Oraons from the Deccan have advanced because they took to agriculture long ago... In North Bengal, extensive lands are being converted into tea gardens, fruit orchards. They cannot keep their land; there is no education for them, no health facilities, no roads, no way of generating income. Nothing is done for them, although so much money is allotted for them. They don't want money; they want facilities; they want to live the life of an honorable poor Indian, but they are denied everything. The tribal are denied everything (Imaginary Maps-III)".The contractor whose brick kiln Gangor works as a daily labour says behind the bodice lays the pure evil in the form of Gangor's breast and Gangor has made 'everyone sin against God'. Devi had shown how media in the modern world sexualized and commercialized the 'exotic' breast by showing the nakedness of 'Third World' (Adivasi World) to the 'First World'. But this sophisticated media or mainstream world never tries to know the real factor of Gangor's engagement as a daily wager in a brick kiln. The real and pathetic scenario of these marginal tribal sections working under this malik mahajan in the brick kiln as a daily labourer can be specifically blamed as the land alleviation and forests management cum forests feeling. The words of Mahasweta Devi can be mentioned worthily, "India makes progress, produces steel, the tribals give up their land, and receives nothing. They are the suffering spectators of India that is travelling towards the $21^{\text {st }}$ century (Imaginary Maps-III)". This photograph actuates a dooms day when police take Gangor into police custody and repeated rapes by the police transforms her into a prostitute and evicted her from her own family, society, and husband. Mary Louisa Cappelli, in her essay, says "The Photograph ends up stealing Gangor's reproductive livelihood by forcing her into a sexually coded spotlight of patriarchal attention, sexual fantasy and community disgust, pushing Upin unto the broader land ledge of insanity and ultimate death (Sites of Commodification and Exploitation in Mahasweta Devis' Breast Stories50)". Gangor is orcastried from her husband, next from her own society and finally from so called civilized society. By her utter undone condition to subsist in the world she adopted forced whoredom and metamorphosed herself as a whore. After carefully studying and considering the whole subject, one question always haunts us from the beginning to the end of the story. Who is responsible for the miserable condition of the protagonist? I am trying to solve in my paper the same answer. The whole story and condition of Gangor lead towards doom and destruction only for the false representation of Upin's photography in a 
renowned newspaper. Upin's photography is not only exaggeration of reality rather it is, according to the postmodern critic Baudrillard a 'Simulacrum'. Simulacrum can be categorized and defined as "the Simulacra are never what hide the truth - it is the truth that hides the fact that there is none. Simulacra are true (Ecclesiastes)". The Simulacra that Baudrillard refers to are the significations and symbolism of culture and media that perceived reality, the acquired understanding by which our lives and shared existence is and are rendered legible. Baudrillard believes that society has become so saturated with these Simulacra and our lives so saturated with the constructs of society that all meaning was being rendered meaningless by infinitely mutable; he called this phenomenon the 'Procession of Simulacra (Wikipedia)'. So Baudrillard calls in the sentence "Simulacra of Simulation, founded on information, the model, the cybernetic game - total operationality, hyperreality, aim of total control (Simulacra and Simulation-81)". Upin Puri showed primitive India by taking photography of Gangor in her breastfeeding condition which actually in the primitive or marginal society a natural phenomenon. But in contrast to his wife Shital, whose breast "Choli is a silicon chest that remains aggressive forever like plastic flowers (Behind the Bodice-03)". In the end of the story, we can find Gangor whose breasts are not breasts at all. Rather, "Two dry scars, wrinkled skin, quite flat. The two raging volcanic creates spew liquid lava at Upin-gangrape-court case-again a rape in lock up (Behind the Bodice-05)".Gangor, in the beginning, part of her life, allowing Upin to take her snap, became the victim of photogenic simulacra. This false representation of Gangor's breasts in a commercial way brings good luck and huge profit to Upin but disastrous consequences and doomsday to Gangor. This acts as a paragon of exotic beauty as 'Other'. This Western Gaze of Indian Primitivism inspired the civilized world. Primitivism came to have many meanings: It often meant a simpler, even cruder style of conception; sometimes it is meant to idealise the popular modern sense. It meant a valorization of the sexual freedom supposed to exist in primitive societies. These different meanings of 'Primitive' were exploited in the various creative representation of tribal societies during the $20^{\text {th }}$ century (Nation in Imagination245)".In such a way, the story Behind The Bodice represents Gangor's breasts as the cruder symbol of primitivism, the superb natural example of crude exotic, Oriental glorification of beauty. This innocent 'Statuesque' beauty of Gangor's 'mammal projection' by Upin thus becomes the cause of her victimization. Gangor's breasts are natural, not manufactured and Upin feels 'that Gangor and her chest were endangered (Behind the Bodice-06)'.

\section{Woman, Ideology and State Apparatus}

In Indian culture, women are considered with the pakriti, power and preservence. They maintain chastity and never lose their bonding with nature because they are similar to nature. These similarities obviously propounded theoretically in the present time by the western as well as eastern ecofeminists. Besides losing of virginity or chastity, society always looks down upon them with utter disgust and humiliation. The repeated gang rape tainted Gangor's virginity by the police in their custody. Here police custody and continuous gang rape by the police act as a repressive state apparatus. The state must be loyal and welfare to the common people, but they are somehow acted as an agent of capitalist. The common person doesn't get any justice. Gangor, the heroine of the story 'Behind the Bodice' undergoes repeated deprivation by the state, power and politics. Louis Althusser's theory and his theoretical, analytical book 'Ideology and Ideological State Apparatus (Notes towards an Investigation)' come naturally. He says-"I shall say rather that every State Apparatus, Whether Repressive or Ideological, functions both by violence and by ideology... This is a true fact that the (Repressive) State Apparatus functioning massively and predominantly by repression (Including physical repression) while functioning secondarily by Ideology (Ideology and Ideological State Apparatus-80)." The rape of aboriginal Gangor by policemen signifies the violation and exploitation carried out by the institutions, protectors of law and order who are the parts of the ideological state apparatus. But here in the story, the policemen act as the agent of 'Repressive State Apparatus', influencing her custodial violence in democratic India. The police and power structure of the society ideologically functions as the Repressive State Apparatus (RPA) agent because the repression is always based upon the politics of violence, whereas the Ideological State Apparatus acts by ideology. The fact is that the state power, police force and law of society always go against the heroine, Gangor. The saddest fact is that the law, power, politics, society and moreover state never try to understand the real tragic fact of Gangor which always remains the unknown version of Gangor's life.

\section{Stigmatization of Women from Myth to Behind the Bodice}

The ancient scriptures of Indian women are revered as Pakriti or Shakti. Purush in our Samkhya Darshan is the ultimate consciousness and Shakti is that divine force herald's completeness to the Purusah. But this Shakti also got an improper dignity in the ancient scriptures or epics. Mahasweta's heroine Gangor as an adivasi woman faces the same indignation and deprivation. From the Mahabharata to the Ramayana, from pre-colonial to the postcolonial period, from modern to the postmodern era that kind of marginalization or devaluations are happening desperately. The desperate suffering and stigmatization of women by the patriarchal false power is the inevitable fate of their lives. It is clear of every sphere in their lives as Indian society still thinks the man is born to rule and women to be ruled. After studying the ancient myths, we can easily understand that all these exploitations are very much intermingled in our Indian society from time immemorial. In the Ramayana, we can find Sita, princess of Mithila, kidnapped by Ravana during her forest sojourn. But Rama banished Sita (pregnant) once again to the forest on the banks of the Ganga because of the suspicion of this subject about her purity. Again in the epic Mahabharata, Draupadi was 
publicly humiliated and disrobed in a full assembly hall in front of her five husbands. Ahilya, the beautiful wife of a sage Gautama whom Indra, the chief of the Gods coveted. Assuming the person of her husband, Indra cheated her by seduction. Gautama being angry, cursed her and turned her into a rock. Through Ahilya's seduction was a fraud. She suffered by being turned into a stone. Most Indian women are symbols of tolerance and still believe that the tolerance and acceptance of the worst kind of humiliation are integral parts of their lives. They find resemblance with Sita, Draupadi, and Ahilya in their day-to-day duties and sincere devotions to family, society, state, and nation. Gangor's story is similar in respect of the responsibility, devotion, purity and Indian ethical pattern of womanhood. All these mythical heroines are archetypical figures who have undergone various types of injustice and suffering by exploiting patriarchal society and being the second sex. Cited upon this context in the precolonial period, the inhuman 'Suttee' custom, according to the postcolonial critic Gayatri Chakaraborty Spivak calls a 'super exploitation'. Gangor's story is not an exceptional example. Somehow or another way, their story and suffering inextricably link with those archetypical figures like Sita, Draupadi and Ahilya.

\section{Rape and Post Rape Oppression of Gangor:}

Rape is synonymous with the power of manhood. The 'rapability' of women's bodies is considered degraded because women's honour lies in their inviolate body. Mahasweta Devi points out the status of that raped women that are unbearably grim and devastating indictments of the social system. These grim and devastating consequences bring into the life of Gangor the female degradation, female submission and stripping of her honour and humanity as well. As if in society, the women have no place and natural habitat to subsist as expected. They must have niche for their livelihood to exist in this world. Devi's heroine Gangor very deliberately entangled with the socially sanctioned male narrative of guilt-ridden womanhood and forced to convert herself into the worst position of sexually exploited or betrayed women. Her woman thus passes through the trajectory of evolution and poignantly charts an intrinsic progression towards composite subaltern womanhood. Mahasweta Devi portrayed the condition of Gangor into three levels; economic exploitation, sexual oppression, and state violence- all three put together made the life of Gangor miserable and torturous. Rajeshwari Sundar Rajan attempts an explanation of the "different ways in which rape and raped woman enter representation of the subject of narrative as well as different policies they endanger within feminism (The Scandal of the State- 61). She also contends that the feminist texts of rape counter narrative determinism by structuring postrape narrative of survival by literalizing rather than mystifying the loss of female selfhood. The story of Gangor doesn't end here. It becomes more pathetic when Upin again visits Jharoa and comes to know the tragic life of Gangor who unfortunately finds after a long searching as a mere prostitute. Gangor is now an active agent of and she returns the look 'as if she says to Upin with her beckoning finger, get thee behind me (Behind the Bodice-155)". Instead of being a passive recipient of looking Gangor now directs Upin's look towards herself. But at that he can't look at her directly. Even that time, it can't arouse an erotic impulse but evokes horrors and guilt within Upin. Gangor angrily says "Look, look, look, straw-chaffs, rags-look what's there (Behind the Bodice-157)". Upin very pathetically observes that Gangor's erotic, fantastic, photogenic breasts transformed as "No breasts, two dry scars, wrinkled skin, quiet flat. Two raging volcanic craters spew liquid lava at Upin ...gang rape ... police ... a court case ... again a gang rape in the lock-up ... now from Jharoa to Seopura ... Seopura to Jharoa ... the contractor catches clients ... terrorizes a public ... plays the song, the song ... U Upin stands up weaving, unsteady ... Upin runs along the tracks (Behind the Bodice- 10)".

\section{Conclusion}

Mahasweat Devi portrayed the travails of women more specifically in three spheres. Economic exploitation, sexual exploitation and state violence are the forms of malicious forces. All these three put together and transformed the lives of women miserably unbearable and tortuous. This is frankly delineated and expressed through the commodification of breast and body as well. What Upin had done to gain more prosperity in his professional life is only possible for the sake of the 'Attention Economy. The attention economy is used in the advertisement or media and this term is directly related to the media studies. A large number of people's attention is a valuable and tradable commodity in the field of business applications to the contemporary fast-flowing society. Therefore, Gangor's breasts' photography grasps the consumer's attention and brings a huge profit to Upin as a symbol of exotic Oriental, primitive representation of underdogs India. On the contrary the breasts feeding the image of Gangor which had been falsely represented gives birth to the narratives of rape, post rape traumatic tale and the tale of prostitution. Here in the information era, people's knowledge is very limited and easily transferred. That's why Upin projects whatever makes everyone believe without justifying its authenticity and probability. She goes through rape, violence, police custody, gang rape, physical torture, psychological trauma, and her ultimate metamorphosis into prostitution. So the line ends with oh God! No justice (Mother of 1084-188). 


\section{References}

[1] Devi, M. (2019). Breast stories. (Gayatri Chakraborty Spivak, Trans.). Kolkata: Seagull Publishers.

[2] Devi,Ma. (2018). Imaginary maps. (Gayatri Chakraborty Spivak, Trans.). Kolkata: Seagull Publishers.

[3] Althusser, L. (2006). Ideology and ideology state apparatus: Notes towards an investigation. New Delhi: Aakar Books.

[4] Singh, S. (2006). Aesthetics of protest: A study of the iorks of Mahasweta Devi. Jaipur: Yking Books.

[5] Vijayasree, C., et al. (2007). Nation in imagination. New Delhi: Orient Black Swan.

[6] Baudrillard, J. (1994). Simulacra and simulation. (Sheila Faria Glaser, Trans.). Michigan: Michigan University Press.

[7] Rajan, R. (2003). The scandal of the state: Woman, law, citizenship in postcolonial India. Durham: Durham University. 